\title{
Justice and Security as Prerequisites for Sustainable Development in the Niger Delta Region.
}

\author{
Letam Don -Baridam, ${ }^{[1]}$ Professor Don Baridam ${ }^{[2]}$ \\ ${ }^{1}$ (Lecturer, Department of Management, Faculty of Management Sciences, Rivers State University of Science \\ and Technology, Port Harcourt, Nigeria.) \\ ${ }^{2}$ (Professor of Organizational Behavior, Department of Management, Faculty of Management Sciences, \\ University of Port Harcourt, Port Harcourt, Nigeria)
}

\begin{abstract}
Over the last few years, the Niger Delta region has witnessed a climate of persistent insecurity. The high rate of unemployment among the youths, and poverty has helped to drive and sustain high levels of violence and criminality throughout the region. This has adversely affected sustainable development. This paper looks at the relationship between justice, security and sustainable development in the Niger Delta, and concludes that without justice and security, the prospects for sustainable development remain a mirage. The paper further argues that sustainable development and security in the Niger Delta region will depend on the right government policy and the willingness of the citizens to cooperate with the law enforcement agencies in preventing crime. It recommends that development, skills acquisition and constructive engagement should be the choice weapons for addressing the problem of justice and security in the Niger Delta.
\end{abstract}

Key Words: Human capital, Justice, peace, security, sustainable development.

\section{Introduction}

Over the last few years, the Niger Delta has witnessed an increase in the number of communal and interstate conflicts. There has been a general feeling of insecurity, which is exacerbated by the high level of poverty in the region. The region is the heartbeat of the Nigeria's economy; yet, its abundant natural wealth stands in stark contrast to its palpable underdevelopment. The high rate of unemployment among the youths has helped to drive and sustain high levels of violence and criminality throughout the delta region. When there is a perceived sense of injustice, driven by the large number of people living in poverty, achieving sustainable development becomes a problem. Going by the law of relative deprivation, when an individual believes that he is being deprived of something to which he believes to be entitled, he reacts in ways that in most cases are inimical to the society. When large sections of the society have no access to their country's natural wealth or political processes, stability is at grave risk. This is the situation in the Niger Delta region in Nigeria.

Today, there is increasing spate of kidnapping, armed robbery, assassinations, politically motivated killings, bombing, high unemployment among the youths, corruption, and inequality in the distribution of resources. No nation can develop in an atmosphere of fear and intimidation. While the Nigerian government is desirous of achieving sustainable development, it has failed to realize that security and justice are the key ingredients in the eradication of poverty and the maintenance of sustainable development. Lack of access to justice is a defining attribute of poverty, and an impediment to poverty reduction and sustainable development. Given the importance of sustainable development in the life of any nation, this paper attempts to discuss the relationship between security and justice as prerequisites for sustainable development in the Niger Delta region, Nigeria.

\section{Security.}

In simple language, security refers to safety from harm, a state of being or existence that is free from danger, threat, anxiety and uncertainty. From this simple definition, security transcends every facet of human endeavour. By implication, security embraces the establishment of proactive and defensive measures to safeguard all persons, materials, and information from every form of danger. Personal security is a basic ingredient in a modern society. When man emerged from the Hobbesian social jungle, he surrended some of his freedom to an agency known as government. This move was to guarantee him better security (safety), away from the social jungle where life was grimly described as "nasty, brutish and short." Government is essentially responsible for the safety of lives and property in civilized societies, as a condition for both the strong and weak segments of society to survive and to attain their maximum human potentials.

From 1999 to date there have been various forms of security threats in Nigeria. Table 1 below shows the various forms of security threats and the zone they emanate. As can be seen from this table, every geographical zone in the country has one of security threat or the other. 
Justice And Security As Prerequisites For Sustainable Development In The Niger Delta Region.

Table 1: Forms of security threats to Nigeria from 2007-2013 and zone they emanate

\begin{tabular}{|l|l|l|l|}
\hline S/N & Security threat & Year & Political zone \\
\hline 1 & $\begin{array}{l}\text { Kidnapping, oil bunkering/oil } \\
\text { pipe line vandalization }\end{array}$ & 1999-till date & South-South (Niger Delta) \\
\hline 2 & $\begin{array}{l}\text { Jos /Nassarawa Crisis Ethnic } \\
\text { crisis-destruction of lives and } \\
\text { property) }\end{array}$ & 199-till date & North Central \\
\hline 3 & Kidnapping, ritual killing and \\
armed robbery & 2007-till date & South East \\
\hline 4 & Aoko Haram crisis & 2009-till date & $\begin{array}{l}\text { North -East, North Central and } \\
\text { North West }\end{array}$ \\
\hline 5 & Armed robbery, drug trafficking & 1999-till date & South west \\
\hline
\end{tabular}

Source: Adapted and modified from Nwagboso 2012

\section{Justice.}

In societies where inequality exists, justice must be based on restitution, and not on the vengeful principle of retribution. Justice should reflect the principle of fairness. Equality, as an essential ingredient of justice, means that all social categories must be treated in such a way and manner that no group considers itself marginalized or excluded. The principle of justice, according to John Rawls (1985), determines how benefits and burdens of society are to be distributed among individuals in a fair manner. How, then, can people decide what is fair, especially in a society of great inequalities and a diverse interpretation of what actually constitutes the good life? According to Rawls (1985:226), "social and economic inequalities should provide the greatest benefit for the least advantaged.',

\section{Economic Development And Peace In Niger Delta.}

The Niger Delta comprises mainly a dense mangrove rainforest located in the southern tip of Nigeria. Nine out of the country's thirty- six states are found within this belt. The region's oil, according to experts in the hydrocarbon industry, comprises well over $90 \%$ of the value of Nigeria's total exports (Asuni 2009).

Geologists and Geomorphologists have identified nine major deltas in the world. Unfortunately, the Niger Delta, which is one of the largest in the world, remains, one of Nigeria's least developed regions. It is this perceived sense of manifest inequality and outright marginalization of the people of the region that has brought so much underdevelopment, poor living standards, agitation and armed conflict to the region.

Why has the Niger Delta region become so prone to conflict and on the radar of the international community? Knowledgeable people date the conflict back to the late 1990s, when it became manifestly obvious to the people of the area that there was little or no political will to frontally address the developmental needs of the Niger Delta region. Previous efforts to develop the region are now generally agreed to be cosmetic by any measure of development, both in conceptual and policy implementation terms at all levels. To this end, oilproducing communities have sought to articulate and advance their interests, including the use of peaceful domestic demonstrations and representations, mobilization of international support, and violent disruption of the operations and installations of oil companies( Suberu; 1995), all in search of sustainable economic development and environmental remediation.

By economic development, we mean the programmed promotion of "more intensive and advanced economic activity through education, improved tools and techniques, more available financing, better transportation facilities, and creation of new businesses''( Redman; 2005). Sustainable development should, therefore, translate into the availability of higher and appropriate technological devices to power economic activities.

The conflict that is ravaging the Niger Delta region today could be attributed to stagnated development that has led to loss of hope among the people of the area. From the setting up of the Willink Commission (1958), the Niger Delta Basin Development Authority (1959), the Oil Mineral producing Areas Commission (1991), to the current Niger Delta Development Commission (2000), the people of the area have not seen any tangible development that can change their sordid situation in what they perceive is the most backward delta in the world- the Niger Delta.

\section{Conditions For Peace.}

There now appears to be a widespread acknowledgement of the peculiar developmental challenges of the Niger Delta region. Years of neglect, political marginalization and mismanagement in resources have predictably resulted in loud calls for "resource control" and the emergence of armed groups, variously referred to as "cult- groups", "gangsters" and "militants", among others. Oil bunkering, and the patronage of idle youths by the so- called political godfathers, has led to increased violence in the Niger Delta. Hardly a day passes now without reported cases of arson, kidnapping and murder. Nightlife that was a major attraction of the 
Garden City of Port Harcourt and other major cities of the Niger Delta, has given way to armed gangs who operate on our streets at will.

The Niger Delta peace and security strategy introduced by the Obasanjo government to complement the muchadvertised Niger Delta Master plan, remained in the main statements of good intentions that are still on the drawing board. While these conceptually laudable initiatives seek to address the economic and social development of the region, the people for whom these policies are designed have very little reason to cheer on any front.

Now, this is the point, at which it has become extremely difficult to control youths of the Niger Delta, who believe that they have little or nothing to lose in towing the path of violence and gangsterism as a response to years of felt injustice. For while the communities take out their bottled-up frustrations on the oil companies that mine their resources and pollute their environment, the oil firms claim they pay tax to the Federal Government whose duty it is to develop the Niger Delta. These oil companies even cite palliative interventions in their corporate social responsibility. Unfortunately, the perception is that what they put back is a far cry from what they take out from the land.

It is against this backdrop that we can locate the current spate of kidnappings, arson, violence and resurgence of militant activities in the Niger Delta that grew out of the political campaigns of 1999. As they competed for office, politicians manipulated rival youth groups to turn against one another. The complications introduced by competing political interests cannot be easily wished away by any serious analysis of the problems of the Niger Delta today.

According to Okechuku Ibeanu (2008:6), "in the Niger Delta, national security contradicts the security of nationals because of the politics of oil". This contradiction is based on the military domination of the Nigerian State for about thirty-nine years. During this period, professional competence amongst military and paramilitary personnel was predictably substituted with ethnic interests and "cross-class solidarity". The issue of development is at the centre of most things that are wrong with Nigeria, and the Niger Delta region, in particular, is the lopsided developmental pattern being implemented by our leaders.

According to Nduka (2006: 9), different people are liable to develop at different rates, partly because of the physical environmental differences among them and partly because of the human characteristics of the people involved. The underdevelopment of the Niger Delta region totally contradicts the submission of Nduka that "the inhabitants of a region blessed with such favourable factors as moderate rainfall, fertile and well drained soil, moderate temperature, abundant mineral and forest resources, are likely to develop more rapidly. The insecurity in the region is a response to many years of obvious neglect.

\section{Human Capital Development.}

One of the major causes of prevailing spate of violence in the Niger Delta region arises from the gross underdevelopment of the area over time. Chaturvedi (2006:25) defines development as a process of social, economic and political change. Human capital reflects the value of our human capacities. Like any other type of capital, it could be invested in through education, training and enhanced benefits that will lead to an improvement in the quality and level of production. Specifically, it is the stock of competencies, knowledge, social and personality attributes, including creativity, embodied in the ability to perform a given task in order to produce economic value. No economy can succeed without having a sound and competent workforce. Developing human capital therefore, requires creating and cultivating environments in which human beings can rapidly learn and apply new ideas, competencies, skills, behaviour and attitudes. Unfortunately, the Nigerian government, including the multinationalcorporations operating in the region has failed to pay adequate attention to human capital development.

The problem of Nigeria appears to linger largely on how to administer the economic and social processes that lead to positive changes. This is a continuous process of formulation, re-evaluation and implementation of set goals in a prescribed period.

The over- centralization of power in a federal system has contributed immensely to the frustration and violence that currently rules the behaviour of youths in the Niger Delta region. In Federal system of governance, decentralization of power, authority and responsibility allows for the integration of the component units of the federating units to feel a sense of belonging. Decentralization involves reassigning decision-making responsibilities on a geographical basis to field service operational units. It may also involve reassignment of tasks based on subject-matter specialization (Chaturvedi, 2006)

When government is distanced from the people, it is meant to serve, the situation results in alienation, suspicion, unemployment agitation and violence as we have in the Niger Delta today. The youths of the area must have hope of a secure future in the form of creation of jobs, training and re-training, programmers, and diversification of the sources of revenue to develop the region. On the vexing issue of employment, the youths of the Niger Delta are genuinely frustrated that people are taking jobs meant for them, thus fueling anger and instigating violence, kidnapping and general insecurity. 
As Judith Asuni (2009) noted, the keys to peace in the Niger Delta, will lie in the ability to reintegrate demobilized combatants successfully, engage and employ the youths, and build strong partnerships with the Niger Delta civil organizations and the federal government.

\section{Security And Sustainable Development.}

Until now, government has apparently relied on the big- stick approach to resolving the intractable developmental problems of the Niger Delta region. The Joint Task Force (JTF), the police and other paramilitary personnel has done a very commendable job in returning normalcy to the troubled Niger Delta region. National security envisages preparation for sorts of defence in readiness for war or an arms race, as was the case during the cold war between the defunct Soviet Union and its western adversaries.

\subsection{The role of the police.}

Conceptually, the police are an organization created and meant for the enforcement of law and order to redress grievances of distressed individuals and groups in the society. The police are to be seen by the public as friendly. In fact, most advanced societies have moved from a violence prone police force to neighbourhood policing that involves everybody in crime detection, prevention and redress. When the police rely solely on coercive instruments in their relations with the public, it becomes a police state.

A police state is a system where the police carry out administration through the supervision of the ordinary citizen. Under such a system, the police force sometimes act secretly with government agencies to make life miserable for its citizens - especially those who are considered to be out of tune with official thinking.

In Nigeria, the police are yet to find answers to recurrent issues of crime, assassinations, kidnappings, and corruption that are plaguing the country. They are very poorly equipped in terms of modern communication gadgets, and rapid response strategies. They are paid poor salary, lack periodic training, and do not have computerized records; these amongst other constraints hinder their efficiency on the job.

The Nigerian Institute of Public Relations (2007:6) in its study on the security situation in the south- south region maintained that law-and-order in the Niger Delta remains a heavy burden on the Nigerian nation. The study identified the neglect of law enforcement agents in terms of basic provisions to make them comfortable and dignified on the job, as a national scandal that needs urgent redress.

The study identified poor motivation as a major source of inefficiency of the police, and argued that they deserve offices, uniforms, raincoats, living quarters and decent salaries. People placed in uncomfortable and often-dehumanizing working environments, cannot be expected to discharge their duties well. The constant tension in the Niger Delta exposes the law enforcement agencies to greater danger. Against this background, the attitude of the police towards the citizens they are deployed to protect, cannot but reflect the difficult circumstances that characterize their operational environment.

\subsection{The role of government}

Thomas Hobbes in Perez (2009) once said that the primary responsibility of government is the maintenance of law and order. For Hobbes, man is self-centered and lawless, and will presume whatever line of action that will achieve his selfish objective to the exclusion of all other consideration, if given the opportunity. When more people in the society or environment subscribe to the above perspective to life, strife, violence, and chaos arise. The consequence of this is that man in such an environment will remain unable to realize his potential. To avoid a situation where a man's existence in society become nasty, brutish and short, the individual surrenders this unrestricted freedom to a sovereign entity that has the responsibility of guaranteeing a minimal level of rights and freedom for all. Thus, any government that cannot guarantee the safety of lives and property has no reason for its continued existence. There can be no meaningful development without stability and good governance.

\section{Solution To The Problem.}

Maintenance of justice and security in any nation is a herculean task particularly, in a developing country like Nigeria. However, certain things can still be done to achieve peace and sustainable development. As a starting point, Nigeria must take a hard look at the root causes of the current security problems besieging the nation in order to find lasting solutions.

8.1. Re-organization of the operational structure of the Nigerian police: There is need to re-organize the operational structure of the Nigeria Police- especially those of them that serve in the Niger Delta region. The current situation in which the police are more interested in providing security to influential individuals and multinational corporations at the expense of the citizens, directly compromises sustainable development and effective security in the Niger Delta region and the country at large. In re-organizing the police and other security agencies, emphasis must be placed on professionalism, recruitment, and training in order to cope with 
modern technology. Majority of the criminals are well trained and very knowledgeable in the use of modern technology. It takes an intelligent and well-trained officer to beat the present crop of criminals.

8.2. Provision of database: Crime prevention requires accurate and up-to-date information. The police and other crime prevention agencies can only do an effective work of policing when they have relevant data that would aid documentation and monitoring of the population. Relevant database should include among others, date of birth, death, fingerprint, photograph, and other personal details that aid in the identification of suspects. Such information must be accessible to both the police and State Security Services, the two main agencies responsible for internal security.

8.3. Public enlightenment: The security agencies cannot do the work of fighting crime alone. The public must be involved. This is because they live with the criminals and know more about them. They must collaborate with the police. To achieve this collaboration, the police authorities should place more emphasis on the police community relations committee (PCRC). The police must resist the temptation of being used as status symbol by some members of the committee to intimidate innocent citizens and free criminal elements from the long arm of the law.

In collaborating with the police, the force must secure the trust of citizens who can provide it with vital information about criminal activities in their neighborhood. Those who provide information to the police must be protected to keep this vital channel of communication open for effective crime detection, investigation and prevention.

8.4. Reducing unemployment: Government must make concerted effort to create job. Youth unemployment appears to be one of the reasons for insecurity in the Niger Delta region. Since government cannot employ all the job seekers, it must try to create an environment where small businesses can grow. There must be stable electricity, good roads, water and schools among others.

In the final analysis, sustainable development and security in the Niger Delta region will depend on the right Government Policy and the willingness of the citizens to cooperate with the police in preventing crime. Human capital development, skills acquisition and constructive engagement should be first choice weapons for redressing the Niger Delta question, rather than relying on the only brute force to resolve the problem. When the youths are meaningfully engaged in economically viable activities, social vices will be brought to rest and peace and development will reign. We have no other way out.

\section{References.}

[1]. Asuni Judith B. (2009) Blood Oil in the Niger Delta. Washington, D.C: U.S. Institute of Peace

[2]. Chaturvedi, A.K (2006), Dictionary of political science, Benin: EPP Book Services Nigeria Limited.

[3 Ibeanu Okechuku Abubakar M. (2008) State Responsiveness to Public Security Needs: The Politics of Security Decision Making-Nigerian Country Study. CSDG Papers No.14 (June).

[4]. Nduka, Otonti (2006) The Roots of African Underdevelopment and other Essays, Ibadan, Spectrum Books Limited.

[5]. Nwagboso, Chris I. "Security Challenges and Economics of Nigeria State (2007-2011) (2012), American International Journal of Contemporary Research, Vol. 2, No, p.238

[6]. Perez, Zagorin (2009) Hobbes and the Law of Nature. Princeton University Press

[7]. Rawls John (1985) "Justice and Fairness: Political Not Metaphysical," Philosophy and Public Affairs (Summer): 223-251

[8]. Redman Charles (2005) “Urban Centers”. Encerta Reference Library, Microsoft Corporation.

[9]. Suberu, Rotimi (1995), Ethnic Minorities Conflicts and Governance in Nigeria, Ibadan: Spectrum Books Limited.

[10]. The Nigerian Institute of Public Relations Rivers State Chapter (2007) Report and recommendations on law and order in the South-South Zone.

[11]. The Willink Commission Report 1958. Report of the Commission Appointed to Enquire into the Fears of the Minorities and the Means of Allaying Them. Presented to Parliament by the Secretary of State for the Colonies, (July). 